\section{Growth Inhibition of Caladium by High Temperature}

\author{
Brent K. Harbaugh and Michael R. Evans \\ Gulf Coast Research and Education Center, University of Florida, 5007 60th \\ Street East, Bradenton, FL 34203
}

Additional index words. Caladium $\times$ hortulanum, tuber, heat stress

\begin{abstract}
Nonplanted Caladium $\times$ hortukmum Birdsey 'Candidum' tubers were exposed to 26 (control), 38,43, or $48 \mathrm{C}$ for 1,2 , or 3 days. Then tubers were planted and forced in a glasshouse for 4 weeks at 18 to $33 \mathrm{C}$ (air). Leaf emergence from tubers exposed to $48 \mathrm{C}$ for 1 or 2 days required 3-12 days longer than leaf emergence from control tubers. No leaves emerged from tubers treated at $48 \mathrm{C}$ for 3 days. Exposing tubers to $38 \mathrm{C}$ for 3 days or $43 \mathrm{C}$ for 1 day did not affect subsequent plant growth. Exposing tubers to $43 \mathrm{C}$ for 2 or 3 days or $48 \mathrm{C}$ for 1 or 2 days resulted in plants with reduced shoot fresh weights and fewer leaves $\geq 15 \mathrm{~cm}$. In a second experiment, planted tubers were forced for 10 days at $26 \mathrm{C}$ so that roots had developed to the edge of the pot and shoots had emerged to the soil surface. These planted (sprouting) tubers were exposed to $43 \mathrm{C}$ for $\mathbf{0 , 4 , 8 , 1 2 , 1 6 , 2 0}$, or 24 hours/day for 1,3 , or 5 days and then forced for 7 weeks in a glasshouse. With 3- or 5-day treatments, days to leaf emergence increased as the hours of exposure to $43 \mathrm{C}$ increased. Only $33 \%$ of planted tubers exposed to $43 \mathrm{C}$ for 24 hours/day for 5 days sprouted. Tubers exposed to $43 \mathrm{C}$ for $\leq 12$ hours/day for 3 days produced plants of similar or greater height, numbers of leaves $\geq 15$ cm wide, and shoot fresh weights, but additional hours of daily exposure decreased these plant characteristics. At 5 days, plant height, number of $\geq 15-\mathrm{cm}$-wide leaves, and shoot fresh weight decreased linearly with increased hours of exposure of tubers to high temperature.
\end{abstract}

Caladium tubers are generally stored under controlled conditions with optimal temperatures ranging from 21 to $27 \mathrm{C}$ (Harbaugh and Tjia, 1985; Marousky and Raulston, 1973). Marousky and Raulston (1973) reported that caladium tubers forced at $26 \mathrm{C}$ produced higher quality plants than tubers forced at 21 or $31 \mathrm{C}$. Conover and Poole (1973) reported that, although shoot growth was best at $31 \mathrm{C}$, the root systems of caladiums forced at $31 \mathrm{C}$ were smaller than those of plants grown at 21 or 26.5C. In general, the literature suggests that caladium tuber storage and forcing should be within an optimal range of a low of $18 \mathrm{C}$ night to a high of 26.5C day (Evans et al., 1992; Wilfret, 1993).

Soil temperatures between 38 to $50 \mathrm{C}$ occur frequently during container production of many ornamentals (Ingram, 1981), causing a reduction in plant growth (Fretz, 1971; Ingram et al., 1986). Muzzell and Joiner (1966) found that exposing caladium tubers to $40 \mathrm{C}$ for 2 weeks before forcing reduced subsequent leaf count, plant grade, and leaf color intensity compared to plants grown from tubers held at $22 \mathrm{C}$. Growers have reported poor-quality caladiums being forced commercially in heat tents

Received for publication 23 July 1993. Accepted for publication 11 Jan. 1994. Florida Agricultural Expt. Station Journal Series no. R-03299. We appreciate Bates Sons and Daughters and Happiness Farms, Lake Placid, Fla., for providing plant material and partial funding for this research. Use of trade names does not imply endorsement of products or criticism of similar ones not mentioned. The cost of publishing this paper was defrayed in part by the payment of page charges. Under postal regulations, this paper therefore must be hereby marked advertisement solely to indicate this fact. or under high temperatures in greenhouses. This research was conducted to evaluate sprouting and growth characteristics of caladiums after short-term exposure of nonplanted or planted tubers to high temperatures.

\section{Materials and Methods}

Air temperature effects on nonplanted tubers (Expt. 1). 'Candidum' caladium tubers from 4 to $6 \mathrm{~cm}$ in diameter (commercially classified as no. 1 size tubers) were exposed to 26 (control), 38,43 , or $48 \mathrm{C} \pm 1 \mathrm{C}$ for 1,2 , or 3 days. Tubers dug 17 Jan. 1991 were stored 24 weeks at 24 to $26 \mathrm{C}$ and had developed $\approx 2.5$ $\mathrm{cm}$-long shoots. After treatment, tubers were planted in $11-\mathrm{cm}$ square pots $\left(650 \mathrm{~cm}^{3}\right)$ in 1 Florida peat : 1 fine sand : 1 horticultural 5.9 dolomitic limestone, 3 hydrated lime, 0.6 superphosphate with frits (FTE-503). Three grams of Osmocote $14 \mathrm{~N}-6.2 \mathrm{P}-11.6 \mathrm{~K}$ controlled-release fertilizer (Grace-Sierra, Milpitas, Calif.) was applied to the soil surface of each pot after emergence of leaf sheaths. Plants were grown in a fan-and-pad-equipped glasshouse with air from $18 \mathrm{C}$ night to $33 \mathrm{C}$ day. Exterior paint excluded $\approx 80 \%$ light, and the midday photosynthetic active radiation was between 400 and $600 \mu \mathrm{mol} \cdot \mathrm{m}^{-2} \cdot \mathrm{s}^{-1}$. A capillary mat subirrigation system supplied water to each pot.

There were 10 tubers per experimental unit and three replications in time. The number of days for the first leaf to emerge and unfurl was recorded. Plant height, shoot fresh weight, and the number of leaves divided into leaves $<15$ $\mathrm{cm}$ wide and $\geq 15 \mathrm{~cm}$ wide were recorded 4 weeks after planting. Means were separated vermiculite (by volume) amended with $\left(\mathrm{kg} \cdot \mathrm{m}^{3}\right)$ by Dunnett's test $(P \leq 0.05)$ for comparison of means with a control.

Medium temperature effects on planted tubers (Expt. 2). 'Candidum' caladium tubers 4 to $6 \mathrm{~cm}$ in diameter were dug 21 Jan. 1992 and stored for 10 to 12 weeks at 24 to $26 \mathrm{C}$. Tubers were subsequently planted in pots $9 \mathrm{~cm}$ in diameter $\left(430 \mathrm{~cm}^{3}\right)$ and grown at $24 \pm 2 \mathrm{C}$ in a growth room for 10 days. At this stage of growth, roots had developed to the edge of the pots and leaf sheaths were just emerging from the soil. These planted tubers then were exposed to $43 \pm 1 \mathrm{C}$ soil for $0,4,8,12,16,20$, or $24 \mathrm{~h} \cdot$ day $^{-1}$ for 1,3 , or 5 days. Planted tubers not exposed to high temperatures were maintained at $21 \pm 1 \mathrm{C}$. After exposure to these treatments, the planted tubers were grown in a glasshouse for 7 weeks with conditions similar to those of Expt. 1.

There were three tubers per experimental unit with three replications in time. Number of days for_the first leaf to emerge and plant growth data were subjected to regression analyses.

\section{Results and Discussion}

Experiment 1. Exposure of tubers to 38 or $43 \mathrm{C}$, regardless of duration, did not significantly affect the days to leaf emergence as compared to tubers exposed to 26C (Table 1). Exposure of tubers to $48 \mathrm{C}$ for 1 or 2 days resulted in a 3- and 12-day delay in leaf emergence, respectively, when compared to leaf emergence of control tubers. When tubers were exposed to $48 \mathrm{C}$ for 3 days, leaves failed to emerge.

Plant height was reduced only when tubers were exposed to $48 \mathrm{C}$ for 2 days or $43 \mathrm{C}$ for 3 days (Table 1). The number of leaves $<15 \mathrm{~cm}$ wide increased for tubers exposed to $43 \mathrm{C}$ for 3 days. The number of leaves $\geq 15 \mathrm{~cm}$ wide and shoot fresh weights decreased for tubers exposed to $43 \mathrm{C}$ for 2 or 3 days or $48 \mathrm{C}$ for 1 or 2 days.

Experiment 2. The number of days to leaf emergence was unaffectedly exposing planted tubers to high temperature for 1 day, but it increased as the duration of 43C exposure increased to 3 or 5 days (Table 2). Only $33 \%$ of the planted tubers exposed to $43 \mathrm{C}$ for 24 h.day ${ }^{-1}$ for 5 days sprouted. Therefore, trend analyses for measured variables for the 5-day exposure were performed without this treatment.

Plant height increased as hours that planted tubers were exposed to high temperature increased for 1 day. Plant height decreased when planted tubers were exposed for 3 days to $43 \mathrm{C}$ more than $12 \mathrm{~h} \cdot$ day $^{-1}$. At 5 days, plant height decreased with increasing hours of exposure to $43 \mathrm{C}$.

The number of leaves $<15 \mathrm{~cm}$ wide increased linearly with an increase in daily hightemperature exposure of planted tubers for 5 days but not at 1 or 3 days. The number of leaves $\geq 15 \mathrm{~cm}$ wide decreased when planted tubers were exposed to $43 \mathrm{C}$ for $\geq 16 \mathrm{~h} \cdot \mathrm{day}^{-1}$ for 3 days, and a linear decrease in large leaves occurred as hours of daily exposure increased for 5 days. 
Table 1. Response of nonplanted 'Candidum' caladium tubers to 26 (control), 38, 43, or 48C for 1,2, or 3 days. Plant growth data recorded 4 weeks after tubers were planted in pots and forced in a glasshouse.

\begin{tabular}{|c|c|c|c|c|c|c|c|c|c|c|c|c|c|c|c|}
\hline \multirow[b]{3}{*}{ Temp $\left({ }^{\circ} \mathrm{C}\right)$} & \multicolumn{3}{|c|}{$\begin{array}{c}\text { Leaf emergence } \\
\text { (days) }\end{array}$} & \multicolumn{3}{|c|}{$\begin{array}{l}\text { Plant ht } \\
(\mathrm{cm})\end{array}$} & \multirow{2}{*}{\multicolumn{3}{|c|}{$\frac{\text { No. leaves }<15 \mathrm{~cm}}{\text { Days of exposure }}$}} & \multicolumn{3}{|c|}{ No. leaves $\geq 15 \mathrm{~cm}$} & \multicolumn{3}{|c|}{$\begin{array}{l}\text { Shoot fresh wt } \\
\text { (g) }\end{array}$} \\
\hline & & & & & & & & & & & & & & & \\
\hline & 1 & 2 & 3 & 1 & 2 & 3 & 1 & 2 & 3 & 1 & 2 & 3 & 1 & 2 & 3 \\
\hline 38 & 15 & 13 & 14 & 27 & 28 & 28 & 1.5 & 1.3 & 1.6 & 1.9 & 2.2 & 1.6 & 42 & 48 & 38 \\
\hline 43 & 15 & 15 & 18 & 25 & 26 & $21^{z}$ & 2.3 & 2.0 & $2.3^{z}$ & 2.0 & 1.5 & 0.4 & 35 & $36^{2}$ & $20^{2}$ \\
\hline 48 & $17^{z}$ & $25^{2}$ & $--^{y}$ & 22 & $19^{2}$ & --- & 2.1 & 1.5 & --- & $0.9^{x}$ & $0.4^{z}$ & --- & $23^{2}$ & $12^{2}$ & $\cdots$ \\
\hline
\end{tabular}

${ }^{2}$ Values in columns significantly different from the control (26C) treatment by Dunnett's test, $P<0.05$.

'Tubers exposed to $48 \mathrm{C}$ for 3 days did not emerge.

Table 2. Response of planted (sprouting ${ }^{2}$ ) 'Candidum' caladium tubers to $43 \mathrm{C}$ for $0,4,8,12,16,20$, or 24 h.day ${ }^{-1}$ for 1,3 , or 5 days.

\begin{tabular}{|c|c|c|c|c|c|c|c|c|c|c|c|c|c|c|c|}
\hline \multirow[b]{3}{*}{ Hours/day at $43 \mathrm{C}$} & \multicolumn{3}{|c|}{$\begin{array}{c}\text { Leaf emergence } \\
\text { (days) }\end{array}$} & \multicolumn{3}{|c|}{$\begin{array}{l}\text { Plant ht } \\
(\mathrm{cm})\end{array}$} & \multirow{2}{*}{\multicolumn{3}{|c|}{$\frac{\text { No. leaves }<15 \mathrm{~cm}}{\text { Days of exposure }}$}} & \multicolumn{3}{|c|}{ No. leaves $\geq 15 \mathrm{~cm}$} & \multicolumn{3}{|c|}{$\begin{array}{l}\text { Shoot fresh wt } \\
(\mathrm{g})\end{array}$} \\
\hline & & & & & & & & & & & & & & & \\
\hline & 1 & 3 & 5 & 1 & 3 & 5 & 1 & 3 & 5 & 1 & 3 & 5 & 1 & 3 & 5 \\
\hline 0 & 36 & 32 & 38 & 23 & 2 & 31 & 2.1 & 2.7 & 0.2 & 2.6 & 2.4 & 3.4 & 37 & 31 & $\overline{42}$ \\
\hline 4 & 29 & 32 & 34 & 21 & 25 & 22 & 3.3 & 2.1 & 2.5 & 2.8 & 2.0 & 1.7 & 34 & 34 & 28 \\
\hline 8 & 36 & 33 & 38 & 24 & 24 & 21 & 3.2 & 1.5 & 3.0 & 2.1 & 2.3 & 1.7 & 32 & 36 & 28 \\
\hline 12 & 38 & 36 & 40 & 26 & 26 & 21 & 2.5 & 2.0 & 2.0 & 2.2 & 2.2 & 1.6 & 37 & 37 & 20 \\
\hline 16 & 33 & 40 & 44 & 26 & 19 & 17 & 3.1 & 2.8 & 3.0 & 2.2 & 1.4 & 0.7 & 34 & 21 & 14 \\
\hline 20 & 36 & 38 & 48 & 25 & 21 & 11 & 1.5 & 1.2 & 4.9 & 1.7 & 1.6 & -0.3 & 33 & 21 & 12 \\
\hline 24 & 35 & 50 & $\ldots-y^{y}$ & 27 & 19 & --- & 1.6 & 2.0 & --- & 1.9 & 0.2 & $\ldots$ & 31 & 6 & --- \\
\hline Significance $^{x}$ & NS & $\mathrm{L}$ & $\mathrm{L}$ & $\mathrm{L}$ & $\mathrm{Q}$ & $\mathrm{L}$ & NS & NS & L & NS & Q & L & NS & Q & $\mathrm{L}$ \\
\hline$r^{2}$ & -- & 0.37 & 0.52 & 0.21 & 0.60 & 0.73 & --- & -- & 0.32 & --- & 0.61 & 0.62 & --- & 0.81 & 0.78 \\
\hline
\end{tabular}

${ }^{2}$ Tubers were planted and forced at $24 \mathrm{C}$ for 10 days. Roots had developed to the edge of the pot, and leaf sheaths were at the soil surface when planted tubers were exposed to high temperatures.

Only $33 \%$ of the tubers exposed to $43 \mathrm{C}$ for $24 \mathrm{~h} \cdot \mathrm{day}^{-1}$ for 5 days had sprouted by the end of this study; thus, this treatment was removed from the regression analyses. 'Linear (L) or Quadratic (Q) regression equations nonsignificant (NS) or significant at $P<0.05$.

Shoot fresh weights were similar for plants grown from tubers exposed to $43 \mathrm{C}$ for all exposure times for 1 day. Shoot fresh weight decreased when planted tubers were exposed to high temperature for $\geq 16 \mathrm{~h} \cdot$ day $^{-1}$ for 3 days. A linear decrease in shoot fresh weight resulted from an increase in daily hours of exposure after 5 days.

In summary, much attention has been given to low-temperature stress on caladiums because growth of this tropical crop is inhibited by temperatures below 16-18C when storing tubers (Marousky, 1974), shipping prefinished potted plants (Harbaugh, 1990), and forcing (Evans et al., 1992). In our study, caladium growth was also inhibited when tubers were exposed to short-term supraoptimal air and soil temperatures. With nonplanted and planted tubers, air or soil temperatures $\approx 43 \mathrm{C}$ for 2 or 3 days and exposure times longer than $12 \mathrm{~h} \cdot \mathrm{day}^{-1}$ caused significant delays in sprouting and reduced plant quality as measured by plant height, number of large leaves, and shoot fresh weight. Higher temperatures (48C for 3 days) or longer exposure (43C for 5 days) completely inhibited sprouting.

\section{Literature Cited}

Conover, C.A. and R.T. Poole. 1973. Influence of shade level and soil temperature on forcing of Caladium bicolor. Proc. Fla. State Hort. Soc. 86:369-372.

Evans, M.R., G.J. Wilfret, and B.K. Harbaugh. 1992. Caladiums as potted and landscape plants. Florida Coop. Ext. Serv. Circ. 1060, Gainesville.

Fretz, T.A. 1971. Influence of physical conditions on summer temperatures in nursery containers. HortScience 6:400-401.

Harbaugh, B.K. 1990. Transit duration $\times$ temperature and fertilization of prefinished caladiums affect subsequent growth. HortScience 25:554555.

Harbaugh, B.K. and B.O. Tjia. 1985. Commercial forcing of caladiums, Florida Coop. Ext. Serv. Circ. 621, Gainesville,
Ingram, D.L. 1981. Characterization of temperature fluctuations and woody plant growth in white poly bags and conventional black containers. HortScience 16:762-763.

Ingram, D.L., C. Ramcharan, and T.A. Nell. 1986 Response of container-grown banana, ixora, citrus and dracaena to elevated root temperatures. HortScience 21:254-255.

Marousky, F.J. 1974, Influence of curing and low temperatures during storage on subsequent sprouting of caladium tubers. Proc. Fla. State Hort. Soc. 87:426-428.

Marousky, F.J. and J.C. Raulston. 1973. Influence of temperature and duration of curing, storage, shipping and forcing periods on caladium growth. Proc. Fla. State Hort. Soc 86:363368.

Muzzell, A.E., Jr., and J.N. Joiner. 1966. Effects of methods of cut, heat treatment and planting placement on forcing caladium spp. Candidum. Proc. Fla. State Hort. Soc. 79:446-451.

Wilfret, G.J. 1993. Caladium, p. 239-248. In: A. De Hertogh and M. Le Nard (eds.). The physiology of flowering bulbs. Elsevier, New York. 